\title{
CHAMPIONING SUSTAINABLE TREATMENT OF OIL PALM BASAL STEM ROT DISEASE VIA BIOLOGICAL CONTROL AGENTS
}

\section{LAI KIM YEN* and NUSAIBAH SYD ALI*}

\begin{abstract}
Oil palm is the most important commodity crop for Malaysia and Indonesia. However, it is being threatened by a disease identified as basal stem rot (BSR) caused by Ganoderma spp. Common approaches such as chemical and cultural control have failed to demonstrate total effectiveness in controlling BSR disease. Nevertheless, these practices cause detrimental effects on the environment. Therefore, the attention on adopting biological control agents (BCA) as one of the sustainable methods to eradicate and control BSR disease is on the rise. The current review highlights on the attempts and outcome of applying various BCA such as fungi, bacteria and actinomycetes as single or mixed application to control BSR disease in oil palm.
\end{abstract}

Keywords: basal stem rot, biological control agent, bacteria, fungi, actinomycetes.

Received: 4 January 2020; Accepted: 2 November 2020; Published online: 7 January 2021.

\section{INTRODUCTION}

Oil palm is the most important commodity crop being planted across Malaysia including Peninsular, Sarawak and Sabah. Planted area of oil palm has reached 5.85 million hectares in 2018 and utilised $60 \%$ of the agricultural lands in Malaysia (Kamarudin et al., 2019). Malaysia's palm oil export was recorded with a rise of $6 \%$ in January-June 2020 with an approximate export value of USD5.50 billion compared to the first half of 2019 (MPOC, 2020). Malaysia is the second major palm oil producer after Indonesia with the forecast of total planted areas of mature palms at 11.75 million hectares in 2019/2020 (Mcdonald and Rahmanulloh, 2019). Oil palm is a golden commodity crop producing versatile raw materials for food industry and non-food industries such as biodiesel and oleochemical.

Regardless of whether large or small scale oil palm planters, Malaysian planters are challenged by the most destructive oil palm disease called basal stem rot (BSR) disease. This devastating disease

\footnotetext{
Department of Plant Protection,

Faculty of Agriculture, Universiti Putra Malaysia,

43400 UPM, Serdang, Selangor, Malaysia.

E-mail: nusaibah@upm.edu.my
}

is caused by Ganoderma spp., white rot fungi that could be seen visibly at the bole of an infected palm tree if the infection is at the advanced stages. There are three species reported to be associated with BSR disease, they are Ganoderma boninense, Ganoderma zonatum and Ganoderma miniatocinctum (Idris et al., 2000; Moncalvo, 2000). However, G. boninense has been identified as the most aggressive major causal pathogen of BSR disease in Peninsular Malaysia (Idris et al., 2000; Wong et al., 2012). Conversely, the most dominant virulent species in Sarawak state particularly in Betong and Miri areas has been identified as G. zonatum causing BSR disease and upper stem rot (USR) (Rakib et al., 2017).

The pathogen causes rotting of the roots, bole and subsequently the stem leading to the failure in delivering water and nutritions from the root to the aerial parts of the palm (Chong et al., 2017). Symptoms observed on mature palms include multiple unopened leaflets, flattening of the crown, pale coloured leaf canopy, presence of basidiocarps at the bottom of the stem (Turner, 1981) and collapse of the palm at the final stages of infection. Early detection of this disease is tough as the palms display noticeable symptoms at advanced stages when the disease severity reaches approximately 60\%-70\% (Chong et al., 2017). 
In addition, all these symptoms could occur as single or in combination depending on the environmental conditions and care given to the palms. No absolute pattern of disease progression has been reported till to date (Chong et al., 2017).

The BSR disease is able to cause direct loss (death of the palm) or indirect loss causing reduction in the number of fresh fruit brunches (FFB) leading to yield losses. For the year 2020, BSR disease infection of planted areas is forecasted to touch 443430 ha or affecting 65.6 million palm trees (Roslan and Idris, 2012). Hence, it is crucial to eradicate this devastating disease to prevent any further direct or indirect loss of productive palms.

There are many approaches that could be adopted to mitigate BSR. The most common is via chemical control by application of fungicide. Hexaconazole has been the typical fungicide used to control BSR. It is applied to symptomatic palms via trunk injection, soil drenching, or a combination of these two methods (Idris et al., 2002; Halimah et al., 2012). Even though hexaconazole fungicide application was proven to increase the productive life-span of an infected palm, the residue and nontargeted beneficial microorganism is of concern. In addition, by the end of 2019, all Malaysian oil palm planters and millers are required to obtain sustainability certification, such as the Malaysian Sustainable Palm Oil (MSPO) or the Roundtable on Sustainable Palm Oil (RSPO) by complying with the sustainability standard requirements in order to export certified palm oil to international markets (Kamarudin et al., 2019). Requirement on the sustainability certification, urges the planters to adopt good agricultural practices (GAP). This could be achieved by minimising the usage of synthetic chemical fertilisers, pesticides, fungicides and weedicides.

Biocontrol could be the best alternative to adopt in controlling the disease without causing any environmental harmfulness ( $\mathrm{O}^{\prime}$ Brien, 2017; Aboutorabi, 2018). In addition, it is also lower in cost compared to the cultural and chemical control methods (Aboutorabi et al., 2018).

\section{AN OVERVIEW: BIOCONTROL OF BASAL STEM ROT (BSR) DISEASE}

The term 'biocontrol' is defined as the incorporation of one or multiple microorganisms such as fungi, bacteria, virus and actinomycetes to suppress the population of disease-causing pathogens; either applied onto the soil or to the plants. These incorporated microorganisms are recognised as biological control agents (BCA) which exhibit antagonistic reaction towards the pathogen. Thus, BCA exhibit the potential to prevent the establishment of the disease or its severity. The
BCA is also highly specific towards the targeted pathogen without affecting the normal flora.

Over the past years, there have been extensive studies on the identification of effective BCA for controlling BSR disease (Musa et al., 2018; Naidu et al., 2018; Muniroh et al., 2019). Their potentials have been investigated initially via various in vitro studies for screening and better understanding purpose prior to greenhouse and field trials. The basic method used to evaluate the efficacy of BCA are through dual culture (Naher et al., 2015; ShariffahMuzaimah et al., 2015), poison agar (Marzuki et al., 2015; Shariffah-Muzaimah et al., 2015) and culture filtrate assay (Shariffah-Muzaimah et al., 2015; Ramli et al., 2016). The higher percentage of inhibition of radial growth (PIRG) value displays higher suppression efficacy the BCA towards the pathogen. The inhibition effect could be due to the ability of the BCA to suppress the growth performance of the pathogen through various mechanisms such as competition for nutrient and space, antibiosis, production of cell wall degrading enzymes (CWDE), and production of secondary or defence metabolites (Heydari and Pessarakli, 2010; Chong et al., 2017; O'Brien, 2017). The BCA may utilise a single or an array of mechanisms in inhibiting a pathogen. In many BCA studies, plant growth promotion (PGP) was one of the benefits demonstrated apart from disease suppression (Nur Azura et al., 2016; Muniroh et al., 2019). In some cases, the degree of suppression by BCA towards plant pathogens tends to be lower when tested in field compared with the result achieved on agar plate for the same BCA. This could reflect the diversity of environment ( $O^{\prime} B$ Brien, 2017) and complexity of interaction between microbes in the soil. Hence, it is crucial to evaluate the suppression of BCA towards the pathogen not only in vitro but also in vivo (Nusaibah et al., 2017). Various genera of BCA will be discussed in this article. Recent studies utilising BCA to control BSR disease of oil palm is summarised in Table 1.

\section{Biocontrol Agent- Fungi}

The most common fungi applied as BCA for pathogen eradication across variety of crops are Trichoderma spp. In Malaysia, the most common Trichoderma spp. proven to be antagonist towards G. boninense are Trichoderma asperellum, Trichoderma harzianum and Trichoderma virens (Naher et al., 2012; Sundram, 2013; Nusaibah et al., 2017; Angel et al., 2018; Ho et al., 2018; Musa et al., 2018). A study conducted by Naher et al. (2015) determined the antagonistic and growth performance of T. harzianum T32 strain against G. boninense on different types of media namely potato dextrose agar (PDA), potato sucrose agar (PSA) and malt extract agar (MEA). Cultural morphology of 
TABLE 1. SUMMARY OF RESEARCH FINDINGS IN THE PAST FIVE YEARS (2015-2019)

\begin{tabular}{|c|c|c|c|c|}
\hline Year & Location & Biocontrol agent & Type of study & Source \\
\hline \multirow[t]{5}{*}{2015} & Peninsular Malaysia & Actinomycetes & In vitro & Shariffah-Muzaimah et al. (2015) \\
\hline & & Trichoderma harzianum T32 & In vitro & Naher et al. (2015) \\
\hline & & $\begin{array}{l}\text { Arbuscular mycorrhizal fungi with } \\
\text { Pseudomonas aeruginosa UPMP3 }\end{array}$ & $\begin{array}{l}\text { In vitro and in vivo } \\
\text { (nursery and bait } \\
\text { seedling) }\end{array}$ & Sundram et al. (2015) \\
\hline & & Cladobotryum semicirculare & $\begin{array}{l}\text { In vitro } \\
\text { (dual culture, } \\
\text { mycoparasitism } \\
\text { test, poison agar) }\end{array}$ & Marzuki et al. (2015) \\
\hline & Sabah & $\begin{array}{l}\text { Multiple strains of Bacillus spp. and } \\
\text { Trichoderma spp. }\end{array}$ & $\begin{array}{l}\text { In vitro } \\
\text { (agar well diffusion } \\
\text { assay, SEM, PIRG) }\end{array}$ & Alexander et al. ( \\
\hline \multirow[t]{3}{*}{2016} & Peninsular Malaysia & Scytalidium parasiticum & $\begin{array}{l}\text { In vitro and in vivo } \\
\text { (nursery) }\end{array}$ & ofe \\
\hline & & $\begin{array}{l}\text { Pseudomonas aeruginosa GanoEB1, } \\
\text { Burkholderia cepacia GanoEB2, Pseudomonas } \\
\text { syringae GanoEB3 }\end{array}$ & $\begin{array}{l}\text { In vitro and in vivo } \\
\text { (nursery) }\end{array}$ & Ramli et al. (2016) \\
\hline & & Streptomyces sanglieri & In vitro & Nur Azura et al. (2016) \\
\hline \multirow[t]{3}{*}{2017} & Peninsular Malaysia & Trichoderma harzianum and Bacillus cereus & $\begin{array}{l}\text { In vitro and in vivo } \\
\text { (nursery) }\end{array}$ & Nusaibah et al. (2017) \\
\hline & Sabah & $\begin{array}{l}\text { Multiple strains of Bacillus spp. and } \\
\text { Trichoderma spp. }\end{array}$ & $\begin{array}{l}\text { In vitro and in vivo } \\
\text { (field) }\end{array}$ & Alexander et al. (2017) \\
\hline & Indonesia & $\begin{array}{l}\text { Trichoderma harzianum, Trichoderma } \\
\text { longibrachiatum, Lasiodiplodia venezuelensis, } \\
\text { Dothidiomycetes sp. }\end{array}$ & $\begin{array}{l}\text { In vitro (chitinase } \\
\text { analysis) }\end{array}$ & Esyanti et al. (2017) \\
\hline \multirow[t]{7}{*}{2018} & Indonesia & Bacillus methylotrophi & $\begin{array}{l}\text { In vitro } \\
\text { (antifungal cyclic } \\
\text { lipopeptides) }\end{array}$ & Pramudito et al. (2018) \\
\hline & Peninsular Malaysia & Trichoderma virens $159 \mathrm{C}$ & In vitro & Angel et al. (2018) \\
\hline & Sabah & omyces s & In vitro & Lim et al. (2018) \\
\hline & Peninsular Malaysia & Trichoderma harzianum & In vitro & Ho et al. (2018) \\
\hline & & $\begin{array}{l}\text { Trichoderma asperellum, Trichoderma } \\
\text { harzianum, Trichiderma virens }\end{array}$ & In vivo (nursery) & Musa et al. (2018) \\
\hline & & Hymenomycetes & $\begin{array}{l}\text { In vitro and in vivo } \\
\text { (nursery) }\end{array}$ & Naidu et al. (2018) \\
\hline & & Streptomyces spp. & $\begin{array}{l}\text { In vitro and in vivo } \\
\text { (nursery) }\end{array}$ & Shariffah-Muzaimah et al. (2018) \\
\hline \multirow[t]{2}{*}{2019} & Peninsular Malaysia & $\begin{array}{l}\text { Pseudomonas aeruginosa UPMP3 and } \\
\text { Trichoderma asperellum UPM16 }\end{array}$ & In vitro & Muniroh et al. (2019) \\
\hline & Indonesia & $\begin{array}{l}\text { Trichoderma sp., Aspergillus sp. and } \\
\text { Mucor sp. }\end{array}$ & In vitro (screening) & Puspita et al. (2019) \\
\hline
\end{tabular}

Note: SEM - scanning electron microscopy; PIRG - percentage of inhabitation of radial growth.

T. harzianum T32 exhibited concentric ring in all media with greenish colony observed on PDA and PSA while yellowish green colony on MEA. The study concluded that, biocontrol activity of T. harzianum T32 against G. boninense varied on different types of media in which the highest PIRG rate (70\%) was recorded on PDA (Naher et al., 2015).
To further understand the mechanism adopted by T. harzianum, Ho et al. (2018) identified the transcripts involved during induced systemic resistance (ISR) of oil palm by analysing the root transcriptomes of oil palm seedlings inoculated simultaneously with both $G$. boninense and T. harzianum compared with either pathogen only 
or BCA only inoculated seedlings. The in vivo study showed that T. harzianum was able to delay or inhibit the development of BSR disease symptoms in BCA treated infected seedlings by modulating genes in the host that are involved in the biosynthesis of phytohormones methyljasmonate (MeJA), methylsalicylate (MeSA) and ethylene antioxidant (L-ascorbate and myo-inositol) and few unique secondary metabolites (Ho et al., 2018).

Naher et al. (2015) also concluded that the inoculation of fungal cell wall suspension of endophytes ( $T$. harzianum, $T$. longibrachiatum, Dothidiomycetes sp., Lasiodiplodia venezuelensis) into oil palm plantlets in Murashige and Skoog (MS) medium and broth was able to induce plant defence mechanism against $G$. boninense by synthesising one of the pathogenesis related protein namely chitinase (Naher et al., 2015).

Recently, new biocontrol candidates' namely ascomycetous mycoparasitic and mycophilic fungi such as Cladobotryum semicirculare (Marzuki et al., 2015) and Scytalidium parasiticum (Goh et al., 2016) were reported with potential suppression of BSR disease. Cladobotryum semicirculare is a type of fungicolous fungus from Hypocreales under ascomycetes genus which consists of the biggest group of sporocarp or fruiting body-inhabiting fungi. Cladobotryum sp. was reported to cause disease outbreaks on mushroom production (McKay et al., 1999) and severe losses in Ganoderma tsugae production in a mushroom farm in Taiwan (Kirschner et al., 2007). This had driven Marzuki et al. (2015) to study their antagonistic or parasitic interaction on G. boninense. In this study, Cladobotryum-liked isolates were isolated from fruiting bodies of $G$. boninense and identified as C. semicirculare. Dual culture test demonstrated that C. semicirculare was able to suppress radial mycelial growth of various Ganoderma spp. (Marzuki et al., 2015). Ganoderma lucidum (G32) and G. boninense G37 were the most suppressed with PIRG rate of $74.8 \%$ and $74.7 \%$, respectively (Marzuki et al., 2015). Poison agar test showed that C. semicirculare was able to inhibit the growth of G. lucidum (G32) with 25\%-49\% inhibition rate and $G$. boninense (G14) with $35 \%-55 \%$ with $50 \%$ or $100 \%$ filtrate concentration, respectively (Marzuki et al., 2015). In mycoparasitism test (in vitro), melanised structures were observed on Ganoderma mycelia which served as protective organs to protect Ganoderma against antagonist effects of C. semicirculare (Marzuki et al., 2015). Marzuki et al. (2015) was the first report to conclude $G$. boninense as the potential host of C. semicirculare. Cladobotryum semicirculare has the ability in reducing the regeneration or recovery of Ganoderma mycelia in mycoparasitism test. Field evaluation on its potential for disease suppression is obligatory. Another ascomycetes fungus, Scytalidium parasiticum AAX0113 isolated from the basidiocarp of G. boninense was studied on its disease suppression efficacy on oil palm seedlings (Goh et al., 2016). Scytalidium parasiticum was recognised as necrotrophic mycoparasite of $G$. boninense when hyphae coiling, short lateral hyphal branch enlarged contact structures and appressorium-like organs were observed in mycoparasitism test. Comparable to $C$. semicirculare, $S$. parasiticum could also suppress G. boninense fruiting bodies regeneration. In the nursery study, S. parasiticum was proven as nonpathogenic to oil palm seedlings. Scytalidium parasiticum could suppress BSR disease by reducing disease severity to $76.6 \%$ on treatment of Ganoderma G10 with S. parasiticum. Nonetheless, S. parasiticum has been proven to contribute in improving the seedlings growth performance with greater leaf area observed in treatments compared to control (Goh et al., 2016).

In a study published by Naidu et al. (2015), a total of seven white rot hymenomycetes were isolated from fruiting bodies of healthy palms and all the isolates were tested for their antagonistic efficacy against G. boninense as well as biodegradation properties. Out of seven isolates, Pycnoporus sanguineus, Trametes lactinea and Grammothele fuligo showed high PIRG values ranging from $81 \%$ $84 \%$ in dual culture study with $G$. boninense. In biodegradation assessment, G. fuligo, P. sanguineus, Rigidoporus sp., T. lactinea and Lentinus tigrinus showed great mass losses in between $19.33 \%$ $32.50 \%$ due to the ability in producing one or more lignocellulolytic enzymes. Grammothele fuligo and $P$. sanguineus isolates demonstrated the best biodegradation activity and were further evaluated on their biodegradation performance on both colonised and uncolonised woods with G. boninense mycelium (Naidu et al., 2017). This advanced study has demonstrated that both G. fuligo and P. sanguineus could efficiently degrade diseased oil palm wood waste in an ecologically friendly manner (Naidu et al., 2017). Moreover, pathogenicity and growth promoting properties of these seven hymenomycetes isolates were also determined by Naidu et al. (2018). Naidu et al. (2018) found that all these isolates were non-pathogenic to oil palm and enhanced vegetative growth of seedlings under greenhouse condition. However, up to date, there is no further report on these hymenomycetes against $G$. boninense. It would be advantageous if a more thorough assessment is conducted based on the response of plant defence enzymes, gene expression and metabolites induced via treatment with these hymenomycetes.

\section{Biocontrol Agent-Bacteria}

Numerous endophytic bacteria have been reported on their antagonistic activity against G. boninense including Burkholderia cepacia (Buana et al., 2014; Ramli et al., 2016) and Pseudomonas 
aeruginosa (Zaiton et al., 2006; Ramli et al., 2016; Muniroh et al., 2019). In the recent research conducted by Lim et al. (2019), P. aeruginosa was successfully isolated from soil of a virgin and undisturbed forest area of Crocker Range. P. aeruginosa in this study caused distortion on hyphae of G. boninense and lowered its density of mycelium (Lim et al., 2019). In ethyl acetate crude extract of this endobacteria, the best inhibitory effect against $G$. boninense with minimum inhibitory concentration (MIC) recorded as low as $0.04 \mathrm{mg} \mathrm{ml}^{-1}$. The compound which may have contributed to the antagonistic effect was identified as 3-demethylubiquinone-9 using Liquid Chromatography-Mass Spectrometry (LC-MS) (Lim et al., 2019).

Ramli et al. (2016) successfully isolated endophytic bacteria from symptomless oil palm root tissues. The isolates were identified as $P$. aeruginosa GanoEB1, Pseudomonas syringae GanoEB3 and B. cepacia GanoEB2. These endophytic bacteria were tested in nursery trial using pre and post treatment against BSR disease infected seedlings. In the study, it was concluded that $P$. aeruginosa GanoEB1 was the best potential BCA among other endobacteria to control BSR disease (Ramli et al., 2016). It was also noted that pre-treated oil palm seedlings have better disease endurance than non-treated seedlings when challenged with G. boninense (Ramli et al., 2016). Further evaluation in the field was emphasised by the authors to verify its effectiveness in suppressing BSR disease (Ramli et al., 2016).

Although $P$. aeruginosa demonstrated great potential in suppressing BSR disease in many studies, $P$. aeruginosa has the disadvantage of being incapable to produce spores. This switches researchers to pay attention to spore bearing bacteria namely Bacillus spp. (Aboutorabi, 2018). Bacillus spp. have been proven to have disease suppression on G. boninense over the years (Susanto et al., 2005; Suryanto et al., 2012; Nusaibah et al., 2017). A novel fengycin (antifungal cyclic lipopeptides) produced by Bacillus methylotrophicus HC51 was detected and exhibited strong inhibition on growth of G. boninense (Pramudito et al., 2018). This new fengycin was characterised with substitution of L-ornithine into lysine (Pramudito et al., 2018). Potential of Bacillus sp. was further evaluated on the possibility of formulating into biofungicide (Puspita et al., 2019). In this study, Bacillus subtilis was formulated into different biofungicide tablets to control G. boninense in oil palm nurseries (Puspita et al., 2019). The best formulation established in this research contained spores of endophytic Bacillus sp., solid waste, talc and tapioca flour in which it successfully delayed the disease incubation period and reduced the disease intensity to $0 \%$ within 140 days. Substantial growth improvement was observed on seedlings compared to the control treatment (Puspita et al., 2019).

\section{Multiple Biocontrol Agents}

Considerable number of research has been done to evaluate the antagonist efficacy of BCA against G. boninense. However, one of the problems associated with biocontrol is the lack of consistency in suppressing disease by application of a single BCA (O'Brien, 2017). Effectiveness of disease suppression of BCA is largely affected by environmental factors (Guetsky et al., 2001). To enhance efficacy and consistency of BCA in suppressing G. boninense, several researches have been identifying efficacy of using multiple BCA in controlling BSR disease. This would allow various BCA to provide synergistic effects for disease suppression by adopting different modes of biocontrol mechanism and survive in broader range of environmental conditions (Chong et al., 2017). However, selection of compatible BCA would be challenging. Combination of BCA must have synergistic relationship in complementing each other to enhance their feasibility on disease suppression as well as promoting plant growth.

A cocktail of Trichoderma spp. including T. virens, T. asperellum and T. harzianum were used by Musa et al. (2018) in evaluating the efficacy of antagonistic activity against $G$. boninense on oil palm seedlings. In the in vivo study, cocktail treatment exhibited disease reduction in infected seedlings at $83.03 \%$ on foliar symptoms and $89.16 \%$ on bole symptoms compared to other single treatments (Musa et al., 2018).

Muniroh et al. (2019) studied proficiency of $P$. aeruginosa and T. asperellum as a mixture of BCA to suppress BSR disease in oil palm. Both microbes demonstrated synergistic relationship that led to a successful biocontrol attempt against $G$. boninense (Muniroh et al., 2019). Nevertheless, both BCA have demonstrated positive phosphate solubilising activity and indole acetic (IAA) production. However, siderophore was only observed in T. asperellum in which all these traits could improve plant growth of the palms. Ability to excrete various cell wall degrading enzymes including chitinase, cellulase and $\beta$-1,3-glucanase were also detected; which could be responsible for the growth inhibition of $G$. boninense in both dual culture and culture filtrate studies.

Furthermore, the consortium of Trichoderma spp. and Bacillus spp. tested by Alexander et al. (2015) had induced the stripping of G. boninense hyphal structure by destroying the cellular structure and highly disrupted, disaggregated, shrivelled and lysis of $G$. boninense hyphal were observed under scanning electron microscopy (SEM). Production of cell wall degrading enzymes (CWDE) could be the factor associated on their antagonist activity in suppressing mycelia growth of $G$. boninense up to 70\% (Alexander et al., 2015). 
According to Nusaibah et al. (2017), a nursery trial was performed to determine disease suppression efficacy on the mixture of T. harzianum and Bacillus cereus. The seedlings were inoculated with $G$. boninense with a novel disease inoculation technique namely dip, place and drench (DPD) (Nusaibah et al., 2017) which differed from the existing method using Rubber Wood Blocks (RWB) (Idris et al., 2006). The result had concluded that single application of $B$. cereus was found to be the most effective treatment in suppressing BSR disease. It had achieved the highest, $94.75 \%$ of disease reduction followed by single applications of T. harzianum $(78.98 \%)$ and a mixture of both T. harzianum and B. cereus $(68.49 \%)$. This validates the importance of in vivo trial to verify the efficacy on disease suppression achieved in in vitro test. Results achieved in in vitro test may be in contrary with the in vivo trial result (Nusaibah et al., 2017). This is because microbes may behave differently in the natural environment compared to the controlled laboratory environment (Nusaibah et al., 2017). Based on the reviewed studies above, it could be concluded that Bacillus spp. may perform better as a stand-alone application than as a consortium of BCA with other genera.

\section{The Potential of Actinomycetes as Biocontrol Agent to Suppress Oil Palm Basal Stem Rot}

Compared to endophytic fungi and bacteria, endophytic actinomycetes obtain much lesser attention on the biocontrol efficacy. Actinomycetes are a group of Gram-positive bacteria with fungal liked morphology due to their branched, filamentous or hyphae-type elongated cells (Singh et al., 2018). It is widely known for the ability to produce a wide range of antibiotics including actinomycetin, micromonosporin, mycetin, actinomyces lysozyme, actinomycin, streptothricin, proactinomycin and streptomycin (Waksman et al., 2010). Most of the actinomycetes are isolated from the genus Streptomyces (Kumari et al., 2013). Actinomycetes are proven to have the ability to promote plant growth contributed by the secretion of siderophores and IAA (Gopalakrishnan et al., 2014). Therefore, Streptomyces could be a potential biocontrol candidate towards various soil borne pathogens. A study has proven the biocontrol ability of a marine isolated Streptomyces vinaceusdrappus in controlling a root rot disease in tomatoes, caused by Rhizoctonia solani (Yandigeri et al., 2015). Besides displaying superior disease reduction in tomatoes plants, treatment plants with respective Streptomyces also have shown significant growth performance advantage (Yandigeri et al., 2015). Besides that, actinomycetes from Streptomyces spp. also demonstrated biocontrol efficacy against various soil borne disease caused by Phytophthora cinnamomic on avocado (You et al., 1996). Pythium aphanidermatum on cucumber (El-Tarabily et al., 2009) and Fusarium oxysporum f. sp. ciceris on chickpea (Amini et al., 2016). However, not many reports on actinomycetes against BSR disease were documented.

The first report in screening potential of actinomycetes against $G$. boninense was documented by Tan et al. (2002). In their research, few Streptomyces spp. were found relatively more effective than Micromonospora spp. in controlling G. boninense. Another in vitro screening of actinomycetes from rhizosphere of oil palm was done by ShariffahMuzaimah et al. (2015) where four isolates (AGA043, AGA 048, AGA 347, AGA 506) were highlighted for their ability to inhibit $G$. boninense. A continuation study on these four isolates was performed and their efficacy of biocontrol against $G$. boninense in powder form after fermentation was tested in BSR disease infected oil palm seedlings (Shariffah-Muzaimah et al., 2018). Isolate AGA347 was reported as the best formulation with $73.1 \%$ of disease reduction compared to other isolates (30.1\%-54.8\%). Isolate AGA347 was then identified as Streptomyces hygroscopicus subspecies hygroscopicus (ShariffahMuzaimah et al., 2018).

In vitro antagonistic efficacy of Streptomyces sanglieri was reported by Nur Azura et al. (2016) in suppressing G. boninense. The antifungal compounds identified from $S$. sanglieri were cycloheximide and actiphenol (Nur Azura et al., 2016). To further study colonisation and potential as a BCA in the oil palm roots, S. sanglieri strain was inoculated into pre-germinated oil palm seeds and observed for six months period. Results showed that S. sanglieri could enhance the plant growth performance including root development, plant height, root length, number of secondary roots and wet weight (Nur Azura et al., 2016). Colonisation of this strain in root area of oil palm seedlings was studied by re-isolating from the root segments one- and sixmonth after inoculation and observed under SEM. Streptomyces sanglieri was found to grow on the root epidermal surface after one-month inoculation and later penetrating the epidermal cell junctions after six-month of inoculation. Both in vitro and in vivo results had recommended $S$. sanglieri as a potential BCA towards BSR disease control (Nur Azura et al., 2016).

In Sabah, a total of 20 soil samples collected from Crocker Range forest was used to isolate potential actinomycetes which have biocontrol ability towards to G. boninense (Lim et al., 2019). Out of 72 types of actinomycetes isolates, A19 was reported to have the highest PIRG value with $80 \%$ and causing hyphae damage on G. boninense under SEM. Besides that, ethyl acetate extract of Steptomyces spp. A19 recorded a minimum inhibitory concentration (MIC) at $0.18 \mathrm{mg} \mathrm{ml}^{-1}$. Several anti-fungal compounds were 
also detected via LC-MS including ribostamycin, benzylmatic acid, landomycin B and salinomycin which may contribute to suppress BSR disease in oil palm (Lim et al., 2019).

\section{CONCLUSION}

Efficacy of fungi, bacteria and actinomycetes as potential BCA in suppressing oil palm BSR disease were proven and documented in many studies. Most of these studies only performed the in vitro assessment and a few reported on the in vivo studies in the greenhouse. However, field trial was lacking, it is crucial to assess efficiency of these BCA in the field environment as BCA may behave differently in the field environment compared to agar plate or controlled environment (greenhouse trial). The interaction of BCA with the complexity of abiotic and biotic factors in the field may affect their efficacy as potent BCA in the controlled environment. In addition, assessment on carrier material for BCA is vital to be studied as there is potential of commercialisation of BCA into bio-fertiliser or bio-fungicide. Exploration of other potential microorganisms is also desirable in expanding the insight of potential BCA in controlling BSR disease. Little concern was placed on the Streptomycetes and more study should be attempted in evaluating their efficacy either as single application or as a consortium with different genera for greater disease suppression through adoption of altered mechanisms. A strict and reliable control measure is necessary to eradicate and prevent further spreading of the disease. The urge to explore natural controlling mechanism will not only be beneficial as it is also sustainable and could be a reliable substitute to synthetic chemical fungicides.

\section{ACKNOWLEDGEMENT}

This work was supported by the Fundamental Research Grant Scheme (FRGS), administered through the Ministry of Higher Education, Malaysia (Grant No: 5540093).

\section{REFERENCES}

Aboutorabi, M (2018). A review on the biological control of plant diseases using various microorganisms. J. Research in Medical and Dental Science, 6(4): 30-35.

Alexander, A; Dayou, J and Chong, K P (2015). Morphological changes of Ganoderma boninense mycelia after challenged by Trichoderma and Bacillus. AIP Conference Proceedings, 1669(1): 20075.
Alexander, A; Abdullah, S; Rossall, S and Chong, K P (2017). Evaluation of the efficacy and mode of action of biological control for suppression of Ganoderma boninense in oil palm. Pakistan J. Botany, 49: 1193-1199.

Amini, J; Agapoor, Z and Ashengroph, M (2016). Evaluation of Streptomyces spp. against Fusarium oxysporum f. sp. ciceris for the management of chickpea wilt. J. Plant Protection Research, 56(3): 257264.

Angel, L; Sundram, S; Ping, B T Y; Yusof, M T and Ismail, I S (2018). Profiling of antifungal activity of Trichoderma virens 159C involved in biocontrol assay of Ganoderma boninense. J. Oil Palm Res. Vol. 30(1): 83-93.

Buana, R F N; Wahyudi, A T and Mathius, N T (2014). Control activity of potential antifungal-producing Burkholderia sp. in suppressing Ganoderma boninense growth in oil palm. Asian J. Agricultural Research, 8(5): 259-268.

Chong, K P; Dayou, J and Alexander, A (2017). Detection and control of Ganoderma boninense in oil palm crop. Springer Briefs in Agriculture. DOI 10.1007/978-3-319-54969-9.

El-Tarabily, K A; Nassar, A H; Hardy, G S J and Sivasithamparam, K (2009). Plant growth promotion and biological control of Pythium aphanidermatum, a pathogen of cucumber by endophytic actinomycetes. J. Applied Microbiology, 106(1): 13-26.

Goh, Y K; Marzuki, N F; Goh, T K; Tan, S Y; Goh, Y K and Goh, K J (2016). Mycoparasitic Scytalidium parasiticum as a potential biocontrol agent against Ganoderma boninense basal stem rot in oil palm. Biocontrol Science and Technology, 26(10): 1352-1365. DOI: 10.1080 / 09583157.2016.1202192.

Gopalakrishnan, S; Vadlamudi, S and Bandikinda, P (2014). Evaluation of Streptomyces strains isolated from herbal vermicompost for their plant growthpromotion traits in rice. Microbiological Research, 169(1): 40-48. DOI: 10.1016/j.micres.2013.09.008.

Guetsky, R; Shtienberg, D; Elad, Y and Dinoor, A (2001). Combining biocontrol agents to reduce the variability of biological control. Phytopathology, 91(7): 621-627.

Halimah, M; Mazinah, Z; Ismail, S and Idris, A S (2012). Determination of hexaconazole in field samples of an oil palm plantation. Drug Testing and Analysis, 4(S1): 112-117. 
Heydari, A and Pessarakli, M (2010). A review on biological control of fungal plant pathogens using microbial antagonists. J. Biological Sciences, 10(4): 273-290. DOI: 10.3923/jbs.2010.273.290.

Ho, C L; Tan, Y C; Yeoh, K A; Lee, W K; Ghazali, A K; Yee, W Y and Hoh, C C (2018). Transcriptional response of oil palm (Elaeis guineensis Jacq.)inoculated simultaneously with both Ganoderma boninense and Trichoderma harzianum. Plant Gene, 13(January): 56-63. DOI: 10.1016/j.plgene.2018.01.003.

Idris, A S; Ariffin, D; Swinburne, T R and Watt, T A (2000). The identity of Ganoderma species responsible for BSR disease of oil palm in Malaysia-pathogenicity test. MPOB Information Series No. 77.

Idris, A S; Ismail, S; Ariffin, D and Ahmad, H (2002). Control of Ganoderma infected palm-development of pressure injection and field applications. $M P O B$ Information Series No. 131.

Idris, A S; Kushairi, D; Ariffin, D and Basri, M W (2006). Technique for inoculation of oil palm germinated seeds with Ganoderma. MPOB Information Series No. 314.

Kamarudin, N; Seman, I A and Masri, M M M (2019). Prospects in sustainable control of oil palm pests and diseases through the enhancement of ecosystem services - The way forward. J. Oil Palm Res. Vol. 31(3): 381-393. DOI: 10.21894/jopr.2019.0030.

Kirschner, R; Arnold, G R W and Chen, C J (2007). Cladobotryum semicirculare sp. nov. (Hyphomycetes) from commercially grown Ganoderma tsugae in Taiwan and other Basidiomycota in Cuba. SYDOWIA-HORN-, 59(1): 114-124.

Kumari, M; Myagmarjav, B E; Prasad, B and Choudhary, M (2013). Identification and characterization of antibiotic-producing actinomycetes isolates. Amer. J. Microbiology, 4(1): 24 pp.

Lim, P H; Gansau, J A and Chong, K P (2018). Streptomyces spp. a potential biocontrol agent against Ganoderma boninense of basal stem rot. J. Oil Palm Res. Vol. 30(2): 265-275. DOI: 10.21894/jopr.2018.0024.

Lim, P H; Gansau, J A and Chong, K P (2019). Biocontrol of basal stem rot pathogen Ganoderma boninense by Pseudomonas aeruginosa. Bangladesh J., Bot., 48(2): 209-215.

Marzuki, N F; Goh, Y K; Tung, H J; Goh, Y K and Goh, K J (2015). Evaluation on the cultural characteristics and antagonistic activities of Cladobotryum semicirculare against Ganoderma boninense in vitro. J. Oil Palm Res. Vol. 27(4): 326-338.
Mcdonald, G and Rahmanulloh, A (2019). Indonesia Oilseeds and Products Annual 2019. USDA Foreign Agricultural Service.

McKay, G J; Egan, D; Morris, E; Scott, C and Brown, A E (1999). Genetic and morphological characterization of Cladobotryum species causing cobweb disease of mushrooms. Appl. Environ. Microbiol., 65(2): 606-610.

Moncalvo, J M (2000). Systematics of Ganoderma. Ganoderma Diseases of Perennial Crops (Flood, J; Bridge, P D and Holderness, M eds.). p. 23-45.

Muniroh, M S; Nusaibah, S A; Vadamalai, G and Siddique, Y (2019). Proficiency of biocontrol agents as plant growth promoters and hydrolytic enzyme producers in Ganoderma boninense infected oil palm seedlings. Current Plant Biology, 20: 100116. DOI: 10.1016/j.cpb.2019.100116.

Musa, H; Nusaibah, S A and Khairulmazmi, A (2018). Assessment on Trichoderma spp. mixture as a potential biocontrol agent of Ganoderma boninense infected oil palm seedlings. J. Oil Palm Res. Vol. 30(3): 403-415. DOI: 10.21894/jopr.2018.0035.

Naher, L; Tan, S G; Yusuf, U K; Ho, C L and Siddiquee, S (2012). Activities of chitinase enzymes in the oil palm (Elaeis guineensis Jacq.) in interactions with pathogenic and non-pathogenic fungi. Plant Omics, 5(4): 333.

Naher, L; Intan, S; Mokhtar, B and Sidek, N (2015). Trichoderma harzianum T32 growth and antagonistic performance against Ganoderma boninense on different culture media. The $3^{\text {rd }}$ International Conference on Biological, Chemical and Environmental Sciences (BCES-2015): 21-23. DOI: 10.15242/iicbe. c0915047.

Naidu, Y; Idris, A S; Nusaibah, S A; Norman, K and Siddiqui, Y (2015). In vitro screening of biocontrol and biodegradation potential of selected hymenomycetes against Ganoderma boninense and infected oil palm waste. Forest Pathology, 45(6): 474-483.

Naidu, Y; Siddiqui, Y; Rafii, M Y; Saud, H M and Idris, A S (2017). Investigating the effect of whiterot hymenomycetes biodegradation on basal stem rot infected oil palm wood blocks: Biochemical and anatomical characterization. Industrial Crops and Products, 108: 872-882.

Naidu, Y; Siddiqui, Y; Rafii, M Y; Saud, H M and Idris, A S (2018). Inoculation of oil palm seedlings in Malaysia with white-rot hymenomycetes: Assessment of pathogenicity and vegetative 
growth. Crop Protection, 110(February): 146-154. DOI: $10.1016 /$ j.cropro.2018.02.018.

Nur Azura, A B; Yusoff, M; Tan, G Y A; Jegadeesh, R; Appleton, D R and Vikineswary, S (2016). Streptomyces sanglieri which colonised and enhanced the growth of Elaeis guineensis Jacq. seedlings was antagonistic to Ganoderma boninense in in vitro studies. J. Industrial Microbiology and Biotechnology, Springer Berlin Heidelberg, 43(4): 485493. DOI: 10.1007 / s10295-015-1724-4.

Nusaibah, S A; Saad, G and Hun, T G (2017). Antagonistic efficacy of Trichoderma harzianum and Bacillus cereus against Ganoderma disease of oil palm via dip, place and drench (DPD) artificial inoculation technique. Int. J. Agriculture and Biology, 19(2): 299-306. DOI: 10.17957 / IJAB / 15.0280.

O'Brien, P A (2017). Biological control of plant diseases. Australasian Plant Pathology, 46(4): 293304. DOI: 10.1007/s13313-017-0481-4.

Pramudito, T E; Agustina, D; Nguyen, T K N and Suwanto, A (2018). A novel variant of narrowspectrum antifungal bacterial lipopeptides that strongly inhibit Ganoderma boninense. Probiotics and Antimicrobial Proteins, 10(1): 110-117. DOI: $10.1007 /$ s12602-017-9334-2.

Puspita, F; Dini, I R and Sari, D (2019). Screening of fungi from oil palm rhizosphere in peat soils and the potential as biological agents against Ganoderma sp. Indonesian J. Agricultural Research, 2(2): 37-49.

Rakib, M R M; Khairulmazmi, A; Idris, A S; Jalloh, M B and Wahida, N H (2017). Ganoderma species of basal and upper stem rots in oil palm (Elaeis guineensis) in Sarawak, Malaysia. J. Acad. UiTM Negeri Sembilan, 5: 27-35.

Ramli, N R; Mohamed, M S; Seman, I A; Zairun, M A and Mohamad, N (2016). The potential of endophytic bacteria as a biological control agent for Ganoderma disease in oil palm. Sains Malaysiana, 45(3): 401-409.

Roslan, A and Idris, A S (2012). Economic impact of Ganoderma incidence on Malaysian oil palm plantation - A case study in Johor. Oil Palm Industry Economic J., 12(1): 24-30.

Shariffah-Muzaimah, S A; Idris, A S; Madihah, A Z; Dzolkhifli, O; Kamaruzzaman, $\mathrm{S}$ and Cheong, P C H (2015). Isolation of actinomycetes from rhizosphere of oil palm (Elaeis guineensis Jacq.) for antagonism against Ganoderma boninense. J. Oil Palm Res. Vol. 27(1): 19-29.
Shariffah-Muzaimah, S A; Idris, A S; Madihah, A Z; Dzolkhifli, O; Kamaruzzaman, S and MaizatulSuriza, M (2018). Characterization of Streptomyces spp. isolated from the rhizosphere of oil palm and evaluation of their ability to suppress basal stem rot disease in oil palm seedlings when applied as powder formulations in a glasshouse trial. World J. Microbiology and Biotechnology, 34(1): 15.

Singh, D P; Patil, H J; Prabha, R: Yandigeri, M S; Prasad, S R; Susanto, A and Lai, H (2018). Evaluation of Streptomyces spp. against Fusarium oxysporum $\mathrm{f}$. $\mathrm{sp}$. ciceris for the management of chickpea wilt. Plant Gene, 159(1): 264-274. DOI: 10.1515/jppr2016-0038.

Sundram, S (2013). First report: Isolation of endophytic Trichoderma from oil palm (Elaeis guineensis Jacq.) and their in vitro antagonistic assessment on Ganoderma boninense. J. Oil Palm Res. Vol. 25(3): 368-372.

Sundram, S; Meon, S; Seman, I A and Othman, R (2015). Application of arbuscular mycorrhizal fungi with Pseudomonas aeruginosa UPMP3 reduces the development of Ganoderma basal stem rot disease in oil palm seedlings. Mycorrhiza, 25(5): 387-397. DOI: 10.1007 / s00572-014-0620-5.

Suryanto, D; Wibowo, R H; Siregar, E B M and Munir, E (2012). A possibility of chitinolytic bacteria utilization to control basal stems disease caused by Ganoderma boninense in oil palm seedling. African J. Microbiology Research, 6(9): 2053-2059.

Susanto, A; Sudharto, P S and Purba, R Y (2005). Enhancing biological control of basal stem rot disease (Ganoderma boninense) in oil palm plantations. Mycopathologia, 159(1): 153-157. DOI: 10.1007 / s11046-004-4438-0.

Tan, C J; How, K C; Loh-Mia, P P; Ismet, A; Getha, K; Seki, T and Vikineswary, S (2002). Bioactivity of selected actinomycetes against Ganoderma boninense. Asia Pacific J. Molecular Biology and Biotechenology, 10(2): 119-125.

Turner, P D (1981). Oil Palm Disease and Disorders. Oxford University Press.

Waksman, S A; Schatz, A and Reynolds, D M (2010). Production of antibiotic substances by actinomycetes. Annals of the New York Academy of Sciences, 1213(1): 112-124.

Wong, L C; Bong, C F J and Idris, A S (2012). Ganoderma species associated with basal stem rot disease of oil palm. J. Applied Sciences, 9(6): 879885. 
Yandigeri, MS;Malviya, N; Solanki, MK; Shrivastava, P and Sivakumar, G (2015). Chitinolytic Streptomyces vinaceusdrappus S5MW2 isolated from Chilika lake, India enhances plant growth and biocontrol efficacy through chitin supplementation against Rhizoctonia solani. World J. Microbiology and Biotechnology, 31(8): 1217-1225. DOI: 10.1007/s11274-015-1870-x.

You, M P; Sivasithamparam, K and Kurtböke, D I (1996). Actinomycetes in organic mulch used in avocado plantations and their ability to suppress Phytophthora cinnamomi. Biology and Fertility of Soils, 22(3): 237-242. DOI: 10.1007 / BF00382518.

Zaiton, S; Sariah, M and Zainal, A (2006). Isolation and characterization of microbial endophytes from oil palm roots: Implication as biological control agents against Ganoderma. Planter, 82(966): 587597. 